UDC 338.2: 664:001

\author{
Nemchenko V. \\ Doctor of Economics, Professor \\ Department of Accounting and Auditing \\ Odessa National Academy of Food Technologies \\ Kanatna str., 112 , Odessa, Ukraine, 65039 \\ E-mail: bossvalera29@gmail.com \\ Nemchenko G. \\ Undergraduate \\ Department of Finance \\ Odessa National Economic University \\ Preobrazhenska str., 8 , Odessa, Ukraine, 65082 \\ E-mail: annem2956@gmail.com
}

\title{
INVESTMENT POTENTIAL OF UKRAINE AND THE POSSIBILITIES OF ITS USE
}

The article states that Ukraine doesn't have an opportunity to attract investments for economic development. At the same time, attracting infrastructure bonds and improving lending will allow to find additional investments and ensure GDP growth.

Key words: revenue bonds, innovative and green friendly.

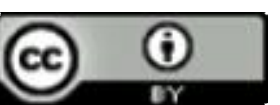

This work is licensed under a Creative Commons Attribution 4.0 International License http://creativecommons.org/licenses/by/4.0/

Statement of the problem and its connection with important scientific and practical tasks. During almost all years of Ukraine's independence, the governments face the problem of finding investments for the growth of the economy. Despite this investment attractiveness was gradually deteriorated, which had negative impact on standard of living, created social tensions in society.

The analysis of the latest publications on the problem. The research of the country's investment potential was reflected in the writings of the scientists and practicing economists: B. Burkinsky, V. Buryakovsky, A.Galchinsky, A.Goncharuk, A.Poddierogin, P. Sabluk, A.Sheremeta and others. The analysis of the latest research and publications indicates that the scientists are not looking for new sources of investment in the absence of economic reforms.

Forming of the aims of the research. The goal of this article is to find new non-standard sources of investment and improve lending, which will allow Ukraine's economy to become ecological, innovative, and competitive.

Giving an account of the main results and their substantiation. According to the data of the Institute for Socio-Economic Research calculations in 20142015, to increase GDP twice in 10 years, it should be increased annually by $7-10 \%$. To achieve this level in 10 years' time an investment of 600 billion dollars per year is needed [3]. Of course, the state doesn't have the amount of money, and it is impossible to attract it because of the absence of reforms, which hinders the development of the country. Over $60 \%$ of the population is below the poverty line and has no savings for development. The banking system is destroyed - there are about 88 remaining from 188 banks. At the same time, the process of "restructuring" the banking system has not yet ended. Banks do not fulfill the main function - lending. This situation is associated with a complete lack of investment attractiveness of the country, distrust of the banking system of Ukraine. This is well illustrated by the income declaration of deputies of MP's, which store millions of Ukrainian hryvnias and US dollars at home. In addition, Ukrainian municipalities hold deposits in banks of 16 billion hryvnia, because they do not know where to put them. At the same time, high business risks are distrustful of banks, so they do not provide loans with funds that do not contribute to GDP growth. To take loans from the outside, with the IMF, becomes impossible, therefore, Ukraine already has huge internal and external debts.

It is well-known the country's investment potential is the capability to attract the necessary resources for development. From this it can be concluded that Ukraine's potential capabilities are limitless (land, labor and other resources), but the real investment potential is not capable of promoting development.

According to the authors of the study "Ukraine 2030: Doctrine of Balanced Development", simultaneous liberalization of exchange rates, shocking increase of prices and tariffs for the population, freezing of social payments, increase of fiscal burden on business lead to lower solvency of the population, dissimulating business activity and threatening paralysis of economic life.

On January 1, 2016, the economy of Ukraine attracted 43.3 billion dollars. US FDI, or $\$ 1016$ US per 
capita, which is the lowest indicator in Europe. [10]

How to solve this complex problem? How to increase the investment potential of the state? To do this, one must conduct a real fight against corruption; monitor every project that allocates funds from the state budget and its effectiveness. For example, the Head of Agrarian Policy and Food for 2018 will plan to allocate 100 million UAH to "support". But where will the money go - to which cooperatives, where and on what principle it is shared nobody knows, which creates conditions for abuse and theft of public funds.

To attract funds from the securities market for the development of the country is a promising direction. "Infrastructure bonds" in transport, energy, housing and communal construction, and others are of particular interest. [1]. A significant proportion of these governmentcontrolled bonds will be able to purchase accumulative pension funds. On the one hand, it will allow to "find" funds for infrastructure projects, and on the other - to earn future pensioners money at minimum risk.

Of course, the attraction of securities is a promising and successful direction, but it is clearly not enough and also due to the fact that the stock market is almost absent in Ukraine.

In our opinion, the main direction of investment attractiveness should be lending to those sectors of the national economy that will contribute to sustainable development, despite the deep crisis of the banking system. Credits in wealthy countries are an important engine of economic development. Only the state can make a loan affordable enough to solve business problems.

It is known that the essence of the loan lies in the relationship between the lender and the plaintiff. These relationships are based on the principles:

- Payment;

- Urgency;

- Reciprocity;

- Target character.

We believe that in today's conditions of development of Ukraine these principles are insufficient and instead of economic development they will "preserve" its raw material, with outdated equipment and specialists with a low level of qualification. In such circumstances, even an increase in investment will not contribute to improving the efficiency of production. All this requires the development of additional principles of lending. The environmental condition, the depreciation of fixed assets (in some cases up to $90 \%$ ), the crisis in labor resources (caused by emigration, war and poor demographic situation and the aging of resources in general) do not allow a breakthrough in GDP growth, and at the same time, raise living standard. For example, only air pollution leads to losses of $15 \%$ of Ukraine's crop [7]. In our country in the XXI century there are no waste processing enterprises. This not only leads to environmental pollution, increased morbidity and mortality. That is why the "new", modern principles of lending in Ukraine should become "green friendly" and "innovative".

The "rudiments" of green lending are in modern Ukrainian banks, such as Oschadbank, Privatbank, Ukr- gasbank, which issued green, preferential consumer loans (replacement of windows, insulation of houses, etc.). In our opinion, this is not enough, the conditions are imperfect, and even this does not solve anything in the state. In addition, as in the western countries, banks should be responsible for the non-environmental loans provided.

All loans granted for innovative development should become preferential and priority for the state. The analysis carried out in agricultural enterprises shows that almost $90 \%$ of the technical means are developed in the former USSR, about 7\% - machines that have been mastered in Ukraine in recent years, the rest belongs to imported machinery, a significant share of which is made up of secondary market machines. The low technical condition of the machines negatively affects their reliability. Due to technical malfunctions and physical wear in Ukraine, $25-35 \%$ of agricultural machinery is used annually, which leads to an extension of the agronomic terms of work and losses of $20-30 \%$ of the harvest [6, p.9.]. All this requires the creation of a powerful agrarian machine-building complex, which today is not in a competitive state compared to the other countries.

Domestic products are characterized by weak innovation. This is evidenced by the indicator of GDP intensity of science, the value of which constantly decreased from $1,06 \%$ in 2003 to $0,83 \%$ - in 2010 . Ukrainian enterprises are faced with competition from products manufactured in the countries, the advanced technologies of which are already in the 6th technological way, while in Ukraine the production is dominated by technologies of the 3rd and 4th technological processes. In such conditions, enterprises in which the strategy of investing in innovation is not assigned a key role, are not competitive [4, p.338.]. It is no accident, V. Geets writes: "... capital is the most important characteristic of the growth resource in the long-term ... it is important to make a step forward now, first of all, to intangible capital, so it is important to evaluate the potential that it is laid in and change its character, because in a competitive relation will not be "[8, c.776.]

Conclusions and prospects of the further investigations. In spite of the lack of investment, Ukraine has a tremendous potential. It prevents the use of this potential because of the corruption with which the struggle began. Today, investments can be quickly attracted through the issuing of infrastructure bonds, the introduction of lending, which should be based on new principles - green and innovative. Ecology should include not only the provision of credit for environmental measures, but banks should be responsible for lending the projects that are harmful to the biosphere. Innovation involves providing loans not to the raw materials sectors of the national economy, which holds back the country's development, but to those areas that are in line with modern scientific and technological progress (in digital technologies, aerospace enterprises, etc.). This will increase the competitiveness and, at the same time, the investment attractiveness of the country, increase export revenues, stabilize the hryvnia exchange rate, and improve the standard of living of the population. 


\section{References}

1. Volkov, S. (2017). Finansovyie mehanizmyi zaschityi investitsiy v usloviyah nedostatka vzaimnogo doveriya. Zerkalo nedeli, (1154).

2. Korablin, S. (2017). Russkaya ruletka. Zerkalo nedeli, (1158).

3. Maksyuta, A. (2017). Plan Marshalla dlya Ukrainyi: novaya vozmozhnost ili ocherednoe razocharovanie. Zerkalo nedeli, (1154).

4. Muzhailo, V. D., \& Kryvonohova, I. H. (2017). Shliakhy rozrobky stratehii innovatsiinoi aktyvnosti promyslovoho pidpryiemstva. In I. I. Savenko, H. M. Stankevych, \& I. O. Sedikova (Eds.), Rekonstruktyvnyi typ adaptuvannia realnoho sektora ekonomiky ta haluzevoi nauky Ukrainy do umov postindustrialnoho suspilstva (pp. 337-348). Odesa: Odeska miska drukarnia.

5. Bondarenko, S. A., \& Shcherban, D. V. (2017). Osnovni tendentsii innovatsiinoho rozvytku pidpryiemstv kharchovoi promyslovosti Ukrainy . In I. I. Savenko, H. M. Stankevych, \& I. O. Sedikova (Eds.), Rekonstruktyvnyi typ adaptuvannia realnoho sektora ekonomiky ta haluzevoi nauky Ukrainy do umov postindustrialnoho suspilstva (pp. 326336). Odesa: Odeska miska drukarnia.

6. Neustroev, Iu. H. (2017). Formuvannia merezhi rehionalnykh tsentriv z tekhniko-tekhnolohichnoho obsluhovuvannia ta doradnytstva $v$ ahrarnii sferi. Odesa.

7. Semerak, O. (2017). Ekologizatsiya dolzhna prohodit po printsipu dekommunizatsii - reshitelno i byistro . Zerkalo nedeli, (1163).

8. Laiko, O. I., Horiachuk, V. F., Osypov, V. M., Osypova, L. A., \& Molina, O. V. (2016). Sotsialnoekonomichnyi rozvytok Ukrainskoho Prychornomoria: vyklyky i mozhlyvosti (B. V. Burkynskyi, Ed.). Odesa: IPREED NANU.

9. Davenport, T. (1993). Process Innovation - Reenginering work through information technology, Harvard Business School Press, Boston

10. Zhylinska, O., Melnychuk, O., Antoniuk, L., Humenna, O., Radchuk, A., Stoliarchuk, Ia., ... Shnyrkov, O. (2017). Ukraina 2030: Doktryna zbalansovanoho rozvytku. Lviv: Kalvariia.

Received 13 October 2017

Approved 27 October 2017

Available in Internet 30.12.2017

Немченко В.В.

доктор экономических наук, профессор

кафедра учета и аудита

Одесская национальная академия пищевых технологий

ул. Канатная, 112, г. Одесса, Украина, 65039

E-mail: bossvalera29@gmail.com

Немченко А.B.

магистрант

кафедра финансов

Одесский национальный экономический университет

ул. Преображенская, 8, г. Одесса, Украина, 65082

E-mail: annem2956@gmail.com

\section{ИНВЕСТИЦИОННЫЙ ПОТЕНЦИАЛ УКРАИНЫ И ВОЗМОЖНОСТИ ЕГО ИСПОЛЬЗОВАНИЯ}

В статье проведено исследование, где доказано, что в Украине отсутствуют внутренние и внешние источники инвестирования, что, к сожалению, сказывается на торможении роста ВВП государства и, соответственно, стремительном снижении благосостояния населения. Низкий уровень инвестиционной привлекательности объясняется тем, что государство не выполняет свои основные функции. Низкий жизненный уровень населения, разрушенная банковская система, нестабильное законодательство в плане налогообложения, девальвирующая валюта, а самое главное - коррупция все это не позволяет и препятствует привлекать инвестиции как внешние, так и внутренние. Целью статьи был поиск новых нестандартных решений данной проблемы, а именно выявление источников инвестирования и усовершенствование кредитования, что позволит укрепиться экономике страны, а также выйти на новый успешный путь развития конкурентоспособного государства, которое соблюдает «зеленые законы», а также является инновационным. Вот почему, предлагается «искать» нестан- 
дартные источники фринансирования, в частности привлечение инфраструктурных инвестиций (в сооружение дорог, мусороперерабатывающих предприятий, развитие коммуникаций и т.д.). Кроме того, сделаны конкретные предложения по реанимации кредитования, используя такие «новые» принципы кредитования как экологичность и инновационанность. Вместе с тем, все эти предложения станут реальными, если их поддержит государство, разработав соответствующие нормативно-правовые документы.

Ключевые слова: инфраструктурные облигации, инновационность и экологичность кредитования.

\author{
Немченко В.В. \\ доктор економічних наук, професор \\ кафедра обліку та аудиту \\ Одеська національна академія харчових технологій \\ вул. Канатна, 112, г. Одеса, Україна, 65039 \\ E-mail: bossvalera29@gmail.com \\ Немченко Г.В. \\ магістрант \\ кафредра фрінансів \\ Одеський національний економічний університет \\ вул. Преображенська, 8, м. Одеса, Україна, 65082 \\ E-mail: annem2956@gmail.com
}

\title{
ІНВЕСТИЦІЙНИЙ ПОТЕНЦІАЛ УКРАЇНИ ТА МОЖЛИВОСТІ ЙОГО ВИКОРИСТАННЯ
}

У статті проведено дослідження, де доведено, що в Україні відсутні внутрішні і зовнішні джерела інвестування, що, на жаль, позначається на гальмуванні зростання ВВП держави і, відповідно, стрімке зниження добробуту населення. Низький рівень інвестиційної привабливості пояснюється тим, що держава не виконує свої основні функції. Низький життєвий рівень населення, зруйнована банківська система, нестабільне законодавство в плані оподаткування, девальвує валюта, а найголовніше корупція - все це не дозволяє і перешкоджає залучати інвестиції як зовнішні, так і внутрішні. Метою статті був пошук нових нестандартних рішень даної проблеми, а саме виявлення джерел інвестування та удосконалення кредитування, що дозволить зміцнитися економіці країни, а також вийти на новий успішний шлях розвитку конкурентоспроможної держави, яке дотримується «зелені закони», а також $є$ інноваційним. Ось чому, пропонується «шукати» нестандартні джерела фрінансування, зокрема залучення інфраструктурних інвестицій (в спорудження доріг, сміттєпереробних підприємств, розвиток комунікацій і т.д.). Крім того, зроблені конкретні пропозиції щодо реанімації кредитування, використовуючи такі «нові» принципи кредитування як екологічність і інноваційність. Разом з тим, всі ці пропозиції стануть реальними, якщо їх підтримає держава, розробивши відповідні нормативно-правові документи.

Ключові слова: інфраструктурні облігації, інноваційність та екологічність кредитування.

\section{Література}

1. Волков С.Финансовые механизмы защиты инвестиций в условиях недостатка взаимного доверия / С. Волков // Зеркало недели. - 2017. - №1154

2. Кораблин С. Русская рулетка / С.Кораблин // Зеркало недели. - 2017. - №1158

3. Максюта А. План Маршалла для Украины: новая возможность или очередное разочарование / А.Максюта // Зеркало недели. - 2017. - №1154

4. Мужайло В.Д. Шляхи розробки стратегії інноваційної активності промислового підприємства / В.Д. Мужайло, І.Г.Кривоногова // Реконструктивний тип адаптування реального сектора економіки та галузевої науки України до умов постіндустріального суспільства: [монографія] / за ред. І.І.Савенка, Г.М.Станкевича, I.О.Седікової. - Одеса: Одеська міська друкарня, 2017, С.337-348.

5. Бондаренко С.А. Основні тенденції інноваційного розвитку підприємств харчової промисловості України / С.А.Бондаренко, Д.В. Щербан // Реконструктивний тип адаптування реального сектора економіки та галузевої науки України до умов постіндустріального суспільства: [монографія] / за ред. I.І.Савенка, Г.М.Станкевича, I.О.Седікової. - Одеса: Одеська міська друкарня, 2017, С.326-336. 
6. Неустроев Ю. Г. Формування мережі регіональних центрів з техніко-технологічного обслуговування та дорадництва в аграрній сфері : автореф. дис. на здобуття наук. ступеня канд. ек. наук : спец. 08.00.05 «Розвиток продуктивних сил і регіональна економіка» / Неустроев Ю. Г. - Одеса, 2017. - 22 с.

7. Семерак О. Экологизация должна проходить по принципу декоммунизации - решительно и быстро / О.Семерак // Зеркало недели. - №1163

8. Соціально-економічний розвиток Українського Причорноморя: виклики і можливості: [монографія] / [О.І.Лайко, В.Ф.Горячук, В.М.Осипов, Л.А. Осипова, О.В. Моліна та ін. ] ; за науковою ред. академіка НАН України, проф. Б.В. Буркинського. - Одеса, ІПРЕЕД НАНУ, 2016. - 810 с.

9. Davenport T. Process Innovation Reenginering work through information technology. - Boston, Harvard Business School Press, 1993. P. 27.

10. Україна 2030: Доктрина збалансованого розвитку / [Жилінська О., Мельничук О., Антонюк Л., Гуменна О., Радчук А., Столярчук Я., Тарута С., Харламова Г., Чала Н., Шнирков О.]. - Львів: Кальварія, 2017. $164 \mathrm{c}$.

Стаття надійшла 13.10.2017 Стаття прийнята до друку 27.10.2017 Доступно в мережі Internet 30.12.2017 